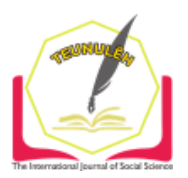

Jurnal Ilmiah Teunuleh

The International Journal of Social Sciences

Vol. 2, Issue. 2, June 2021

E-ISSN: $2746-4393$

\title{
MARKETING STRATEGY TO INCREASE SALES VOLUME
}

\author{
Tarmizi \\ STAIN Teungku Dirundeng Meulaboh \\ trmizi9@gmail.com
}

\begin{abstract}
Competition between entrepreneurs, especially traders in luring consumers so as to increase sales. And one way is to implement a marketing strategy. Marketing strategies must be done effectively so that sales can increase. Marketing activities generally focus on products, pricing, policy ditribusi, and promotional methods that in this case are known as the marketing mix. Marketing mix activities play an important role for the survival of a company. But marketing strategies are sometimes carried out on the basis of conventional economic principles, therefore in this study will be researched about marketing strategies in an Islamic perspective.
\end{abstract}

Keywords: Marketing Strategy, Effective Strategy, Islamic Economic Perspective.

\section{A. Introduction}

Marketing strategy is a very important thing and affects a business or business. Therefore, it is not surprising that every company conducts various marketing strategies in order to increase its sales volume. With the increase in sales volume, the company will also get the desired profit. The better the marketing strategy used by the company, the greater the opportunity for the company to expand its market share.

The development of the business world at this time shows the symptoms of increasing competition towards broad market mastery. Large companies and small companies, compete with each other and race to seize the marketing place in a variety of ways and efforts so that companies can sell as many products as possible to consumers in need. Therefore, the company must get a wide market with a well-mastered marketing strategy method. 


\section{B. Method}

This research is descriptive with quantitative methods. This research leads to the disclosure of a problem or situation as it is and reveals the facts, although sometimes given interpretation or analysis. Quantitative research method can be interpreted as a research method based on the philosophy of positivism. It is used to research on specific populations or samples, data collection using research instruments, and quantitative or statistical data analysis.

\section{Results and Discussion}

\section{Understanding Marketing Strategies}

According to Charles, Strategy is the whole concept of how a company organizes itself and all activities with the aim that the business run successfully conducts competition and yields to shareholders. Meanwhile, according to Assauri, marketing strategy is a series of objectives and objectives, policies and rules that give direction to the company's marketing efforts from time to time at each level, reference and allocation. Especially in response to the company in the face of the changing environment and competitive circumstances. While the marketing strategy according to private is an overall system of business activities through planning, pricing, promoting, and distributing goods and services that satisfy and meet the needs of buyers.

Henry Mintzberg defines strategy as 5P, namely: strategy as Perspective, strategy as Position, strategy as Planning, strategy as Pattern of activity, and strategy as Fraud i.e. secret deception. As Perspective, where strategy in shaping a mission, the mission describes the perspective to all activities. As a Position, where the choice is sought to compete. As Planning, in terms of strategy determine the objectives of the company's performance. As a pattern of activity, where in a strategy is formed a pattern, namely feedback and adjustment.

Therefore strategy is a broad and integrated unity of plan that connects the internal strengths of the organization with the opportunities and threats of its external environment. Therefore, the strategy is always related to the evaluation and selection of alternatives available to a management in achieving the goals that have been set. There are two big variables in a marketing strategy: a controllable variable and an uncontrollable variable. (Alex D.Triyana 1985:19). The variable can be briefly described as follows: 


\section{Variables uncontrolled}

a. State of competition

The state of competition is a difficulty for an entrepreneur to guess when a new rival will appear. Therefore, entrepreneurs must always improve their products and services or business services. Service providers or entrepreneurs should not just shut up because they feel that no new rivals have emerged.

b. Technological developments

The emergence of new technologies that can improve the production process both in terms of efficiency and in terms of models is difficult to predict. To overcome this, entrepreneurs must try to use new technologies faster than their rivals.

c. Politics and Economics

Changes in government regulations in the economic field, or changes in politics can affect the course of business activities because it can affect purchasing decisions and this is difficult to predict.

d. Natural Resources

In some ways, these natural resources are hard to predict when they are reduced or new sources are found. With expensive fuel oil will certainly affect the cost of other needs so as to reduce demand or could be switching to replacement products or services. Although the above variables are considered uncontrolled variables. But in some aspects can actually be foreseen by entrepreneurs or managers based on his experiences in the past.

\section{Variables Controllable}

a. Market segmentation

In marketing wisdom the entrepreneur must set his or her target direction and marketing strategy. Whether the marketing objectives are aimed at all levels of the consumer community or just set a certain market segment only.

b. Marketing mix

Marketing mix is mixing marketing activities to find the maximum combination so as to bring the most satisfactory results.

C. Marketing Budget

Namely the strategy of determining the amount of funds for marketing activities that greatly influence the success of marketing. Because in general, if the funds increase for marketing activities, the number of sales will increase.

d. Timing 
Entrepreneurs should be able to keep the time, when he should start marketing his goods and services, or when a service should and start opening.

From the various understandings and definitions of marketing strategies above, it can generally be defined that the marketing strategy is a plan of a series of maneuvers, covering all elements that are invisible and invisible, to ensure success in achieving goals. Therefore, marketing strategy has the following characteristics:

1. Goal-directed actions, which are activities that show what the organization wants and how to implement it.

2. Consider all internal strengths (resources and capabilities), and pay attention to opportunities and challenges.

\section{Marketing Strategy Steps}

An understanding of the needs and desires of buyers varies into guidelines for the design of marketing strategies. Buyers usually show different preferences and priorities of different products or services.

With regard to the very broad market conditions and having a diverse buying orientation in each market, a company must be able to identify the most attractive market segments and the company can meet them effectively. Therefore, before managing a business or business to market their products or services first they must be able to understand and know the steps that must be taken to launch their marketing strategy so that the planned and carried out is on target, so that the purpose of the marketing can be realized. Here are the steps to be taken in a marketing strategy in kotler's opinion that says that the heart of modern marketing strategy is segmenting, targeting, and positioning (STP):

\section{Market Segmentation}

A company is unlikely to be able to serve all potential customers in a very wide market, because the prospect is too many and the demands of their purchase are different. Therefore, companies need to identify market segments that can be served effectively.

The market consists of a lot of different buyers in several ways, such as desire, financial ability, location, buying attitude and buying practices. From these differences that then require the company to segment the market. Where market segmentation is the process of grouping consumers who were originally heterogeneous (broad) into segments that have the same or homogeneous desires, needs, preferences and 
behaviors of purchases. There are several variables that can be done by companies for this market segmentation including:

Geographic Variables, these variables for example group in a specific area.

a. Demographic Variables, which are variables that group in age, gender and opinion.

b. Psychographic variables, which are a way of grouping consumers in one personality, social class and lifestyle.

c. Behavior Variables, which is a way of grouping consumers in one behavior for example; opportunities, benefits sought, user status, usage level, loyalty status, buyer readiness stage and attitude.

In order for market segmentation to run well and useful, it is worth noting the following characteristics:

a. Measurable, it means that the market size and purchasing power in this segment can be measured even though there are some variables that are difficult to measure.

b. It can be reached, meaning the extent to which this segment can be effectively achieved and served, although some are difficult to reach.

c. The expected segment size, meaning how much segments must be reached in order to be profitable.

d. Can be implemented, meaning the extent to which an effective program can be implemented to manage this segment.

\section{Target Market}

If market segmentation is an analysis of consumers, while the target market is a managerial decision about who or which segment the company will serve. Thus, once the market segments are known, the company then needs to evaluate and continue by deciding which market segments to cover, then choosing which segments to serve. To evaluate the segments that are already known there are three factors that can be studied, namely:

a. Segment size and growth

The company should collect and analyze data on the latest sales, projected sales growth rate and expected profit margins for different segments, then choose which segments are expected to be most appropriate.

b. Structural attractiveness of segments.

A segment may have a size and growth that matches what is expected, but it is not necessarily attractive in terms of profitability, so the company still has to study 
the main structural factors that affect the attractiveness of the segment in the long run.

c. Goals and resources

The Company should consider its objectives and resources in relation to the market segment. Although there are good segments, but it can be rejected if not prospective in the long run. Furthermore, although the segment is good and prospective in the long run, it remains to be considered the ability of the company in providing its resources, for example, the skills of its implementing personnel to enter the market even better skills than its competitors.

\section{Market Positioning}

Market position is a process of building and maintaining a certain place (image) in the market (consumer mind) about what orgaization and or individuals have to offer.

James L. Heskett describes this process as follows:

The most successful service companies are those who are able to separate themselves from the "pack" to achieve certain positions that differ from those of their competitors. They distinguish themselves by changing the general characteristics (having certain characteristics that are different or unique from others) of the industry, so that the difference becomes a competitive advantage.

So the position perspective leads to the understanding that the position is covering communication issues with regard to the psychological position of a product that exists now in the consumer's mind. In other words, the focus of that position is to embed a certain desired image in the consumer's mind rather than with regard to the product itself.

Therefore, after the company decides which market segment to enter, it must also be decided which position to occupy in that segment. To determine the market position, there are three steps as follows:

a. Identifying a Competitive Advantage

If the company can determine its own position as providing additional value to the selected target, then it gains a competitive advantage, for example by offering a quality service, then it must provide quality services as well. Therefore, a company can distinguish its bids so that they differ from competitors' bids, for example distinguished by product, service, personnel, and image.

b. Choosing a Competitive Advantage

Once the company has found a potential competitive advantage, it must then 
Analysis of the Physical Condition of the Aceh PON Rugby Atlet 2021

choose one competitive advantage as the basis for the policy-taking of its positioning, and it must also be determined how much difference and difference is used for its promotional activities.

c. Realizing and Communicating Positions

Furthermore, once the position has been chosen, the company must take steps to realize and communicate the desired position to the target consumer. If the company decides to build a position on the basis of better quality and service, then it must realize that position. That position can continue to grow gradually adapted to the ever-changing marketing environment.

\section{Conclusion}

Marketing strategy is a set of objectives and objectives, policies and rules that give direction to the company's marketing efforts from time to time, at each level, reference and allocation, especially in response to the company in the face of the changing environment and competitive circumstances. There are three marketing strategy steps: market segment, target market, market positioning.

\section{Blibliography}

Alma, B. (2009). Manajemen pemasaran dan pemasaran jasa edisi Revisi. Cetakan Kelima. CV. Alfabeta. Bandung.

Assauri, S. (2015). Manajemen Pemasaran. In PT RajaGrafindo Persada.

Dhian, S., Malik, D., \& Hasiholan, L. B. . (2020). Marketing Strategy Analysis In Increasing Sales Volume In Pure Building Stores, New Tuntang. Journal of Management, 6(1). http://jurnal.unpand.ac.id/index.php/MS/article/view/1488

Hidayati, A., \& Yansi, M. (2020). Role Of Social Media in Marketing of Micro, Small, and Medium Enterprises (MSMEs) Product During Covid 19 Pandemic. Jurnal IImiah Teunuleh, 1(2). https://doi.org/10.51612/teunuleh.v1i2.39

Keegan, W. J., \& Green, M. C. (2016). Global Marketing, Global Edition. In Pearson Education M.U.A.

Kotler, P., \& Keller, K. L. (1997). Marketing Management, 15th Edition. In Pearson Education Limited.

Mudjarad Kuncoro. (2005). Strategi Bagaimana Meraih Keunggulan Kompetitif. Erlangga.

Nafiuddin, N., \& Hamdan, H. (2020). Utilization of Digital Marketing to Improve Sales Volume of MSME's Products. Journal of Digital Marketing and Halal Industry, 2(1). https://doi.org/10.21580/jdmhi.2020.2.1.5282 
Rusdi, M. (2019). Strategi Pemasaran untuk Meningkatkan Volume Penjualan pada Perusahaan Genting UD. Berkah Jaya. Jurnal Studi Manajemen Dan Bisnis, 6(2). https://doi.org/10.21107/jsmb.v6i2.6686

Swastha, Basu, I. (2014). Manajemen Pemasaran Modern. In Liberty, Yogyakarta. https://doi.org/10.1017/CBO9781107415324.004 